\title{
The Real Power of the Social Media, the Interpretation of the Establishing Communication Ways, as Illustrated by the Turkish Assistance during the Kosovo Crises
}

\author{
Njomza KRASNIQI \\ $\mathrm{PhD}$ Candidate \\ European University of Tirana \\ Department of Political Science \\ Profile Communication
}

Abstract

As it is always with new inventions in human history the role they play in their early stages is mostly none acknowledged before they make a more widespread impact. The social media is one of them. Due to the new aspects that this relatively new kind of media its role is mostly negligee in favors of the more vastly popular other forms. In the kind of era that we live technology means that the place where we get the information is irrelevant in the grand scheme of the things, however that does not mean that the impact is lesser or higher. To make the example more clear even though a news that the currency is going to raise or lower in the USA- for example its mostly limited to the USA citizens it has a dire impact in the rest of the world, but even though the means for this news is the generic media, the ones to give the means to understand and make amends to prepare for the consequences to the rest of the world. Due to this kind of functionality is always difficult to separate where the generic forms of the media begin and where the social media begin. What is interesting is that this function of social media begins since the first forms of the internet and it's just more pronounced nowadays. As an example of this functionality the more prominent one is the way Turkey interfered in the Kosovo Crises. More than the generic news and political affiliation at the time the most impact in the public opinion did the social media. This paper is a research in this regard. It's not very detailed and it shows a general picture of the situation and only deal with the main aspects of the behavior of the social media, however is a beginning which shows the great impact all forms of communications, especially the social media.

Key Word: Communication, Social Media, Interpretation, Media reality, Real life reality, Turkey, Kosovo.

\section{INTRODUCTION}

Generally when we speak of social media our first instinct is to think about the facebook, or other WebPages that promote socializing. And in a way this is true. The social media as we perceive it are the WebPages that promote interaction thru the internet, and some of these connections are bound to last a lifetime ${ }^{1}$. However the less promote side of the social media is that it can and actually does change the perception of the way we perceive reality.

Thru the social media we don't only find a way to interact with others, which is a necessity for the human being, and also an instinct, but the less studied aspect of the social media is how it is building trends and changing the perception of different things or matters.

Due to the somewhat impersonal type and anonymity that social networks ${ }^{2}$ offer (you can lie about how old you are, where you live or how you look, etc) it make possible for the majority of the people to find a group to belong too and how to interact in a successful way with that group.

\footnotetext{
1 Brown, E., \& Cloke, J. (2004). Neoliberal reform, governance, and corruption in the South: Assessing the international anti-corruption crusade. Antipode, 36(2), 272-294.

2 Axford, B., \& Huggins, R. (2003). Towards a political sociology of the Internet and local governance. Telematics and Informatics, 20 , 185-192
} 
Also it make able to meet people thru different countries, no matter the distance, and by doing that providing new point of views or ideas, or a simple new way to look at the world. And by doing that introduce new information to the group you are interacting with and that bring a new perspective on what you thought you knew.

Now this is a very large subject and it is not possible to make a study of it in a few pages, but there is an example that scraps the top of the iceberg and show how a few chartrooms and an exchange of information can change a whole perspective.

The case I am studding is how Turkey influence came into being during the Kosovo Crises. This is a isolated happenstance and there were different factors that contributed to it despise the social media, how the interacting way and the way it came into being is wholly due to the social media.

However this is a area that hasn't been studied enough and it needs more research and dedication, since social media nowadays is becoming a power on its own and up until now it is not controlled but being driven by momentous trends and whims of organized groups.

\section{The purpose and objectives of the study.}

The object of this study is to demostrate the role that the primery forms of the social media, such as chatrooms, blogs and communities on the web played during the Kosovo crise, in not only serving as main points of information, especially for the youth of population but also in provideing help and donations to the refuges from Kosovo and how it put in touch generations separated by decades or more ${ }^{1}$.

\section{Research question, hypothesis and methodology of the study.}

This work is a description of the situation that developed in Turchey and Kosovo in 1999-2000, during the Kosovo war and the way most of the donations and information were provided by the social media more then the other legal authorities such as media or the Public media². The different data was collected thru different sources, mainly statistical ones which are detailed in more depth in part fifth.

3.1.Our working hypothesis is: How the social media chnaged the perception of albanians from Kosovo living in Turchey?

\subsection{The importance of this research}

Even though has been many studies for the role the media played in the war of Kosovo, there is next to none regarding how the social media impact the perception of reality since the early days of its usage. The data obtained from the field and different roare processed under the program SPSS Advanced Statistics

\section{Social media in Kosovo and Turkey.}

It sound strange to think about it but one of the main factors that being under the Serbian occupation brought for Kosovo, was that emigration had a very big influence in the way the internal economy was equilibrated. Most of the income was coming from the Albanians of Kosovo whom migrated outside the country, since due to the occupation the possibility for Albanians to find a job on their own country was almost impossible. ${ }^{3}$

So most of them migrated in Europe or Turkey, some for financial reasons and others for more existential reasons; insuring to stay alive.

\footnotetext{
${ }^{1}$ Brown, E., \& Cloke, J. (2004). Neoliberal reform, governance, and corruption in the South: Assessing the international anti-corruption crusade. Antipode, 36(2), 272-294.

${ }^{2}$ Axford, B., \& Huggins, R. (2003). Towards a political sociology of the Internet and local governance. Telematics and Informatics, 20, 185-192

${ }^{3}$ Brown, E., \& Cloke, J. (2004). Neoliberal reform, governance, and corruption in the South: Assessing the international anti-corruption crusade. Antipode, 36(2), 272-294.
} 
There have been different fluxes before the $60^{\text {th }}$ of Albanians migrating not only to Europe but also to Turkey, but up until the 1990 the contact between them as a community was sparse and missing. In most cases there were instances where families have lost connections with each other, due to this kind of migrating.

The more interesting fact that we need to specify is that Turkey and Albanians share a very close mentality, and the way they perceive life and habits is similar. Even some of the traditions are the same. However despite this, prior to 1990 the communication and information between the locals (Albanians living in Kosovo) and the outsiders (Albanians living in Turkey) was at the best way sparse.

Now this hold true until the 1990; and then with the development of the net and the first forms of the chat room and blogs, this whole picture change, and missing connections came into being once more. New communication ways were established and the lost families in most cases came into contact with each other.

The part that illustrates this best way is the way the connections were reenacted during the Kosovo crises. Most of the families that had been established there for decades and hadn't made contact with the part of the family back in the motherland came into play, precisely during this period ${ }^{1}$.

The main way of communication were dedicated chat rooms whom purpose was to gather helps for the refugees and upholding the defensive war that was taking place in the area. Its most interesting to note that in the primary forms of the social media, its impact role is much more pronounced that in the late years².

A guessing thought about this output would be that the more sophisticated the technology become and the more widespread, it make it much more difficult to focus in a topic and to use it to make an impact in a precise way.

\section{Social media and the Crises of Kosovo}

The role that the media ${ }^{3}$ played during the war of Kosovo is a much heated debate then most of the actual issues in the world; however this is not part of this research 4 . The main point of the paper is the role the social media played in providing facts and help in the aiding of the refuges of Kosovo war. The data below was collected using different resources such as statistic publications of Turkey and Kosovo Institute of statistics, and also international publications of statistics such as Gallup and World Bank.

The role of the social media is studied in the aspect of how it made the possible connections and the impact it made in connecting two communities whom even though came from the same country at the beginning were ${ }^{5}$ separated by years of miscommunication and contact, and the role they played in upholding each other.

Even though this communication began since the early 1990 the pick time is in the 1999-2000, especially during the Kosovo Crises. It made possible not only the reconnecting of the two communities, but it also made availed the actual collaboration that exists between the two countries. Most of the investments in Kosovo come from the Turkey, and even most of the trades and business is very much connected with Turkey community.

\section{Analyses, Data Interpretation}

- $\quad$ According to the information gathered from different statistical data and research it shown that prior to 1990 it was this percentage of communication between Turkey Albanian Community (TAC) and the Albanian Community in Kosovo (KAC), 15\% of them kept touch thru traveling every two weeks, while $15 \%$ of them had a direct family member in Kosovo whom they would see once a year, as $4 \%$ of them kept in touch thru chat rooms, while according to data shows that $66 \%$ of the

\footnotetext{
${ }^{1}$ Axford, B., \& Huggins, R. (2003). Towards a political sociology of the Internet and local governance. Telematics and Informatics, 20, 185-192

2 Brautigam, D. (1992). Governance, economy, and foreign aid. Studies in Comparative International Development, $27(3), 3-23$.

${ }^{3}$ Braman, S. (2006). Change of state: Information, policy, and power. Cambridge, MA: Massachusetts Institute of Technology Press. ${ }^{4}$ Bernhard, N. E. (1993). Ready, willing, able: Network television news and the federal government, 1948-1953. In W. S. Solomon \& R. W. McChesney (Eds.), Ruthlesscriticism: Newperspectives in U. S. communication history (pp. 291-312). Minneapolis: University of Minnesota Press.

${ }^{5}$ Bertot, J. C. (2003). The multiple dimensions of the digital divide: More than the technology 'haves' and 'have nots'. Government Information Quarterly, 20(2), 185-191.
} 
statistic show that there were no communication contact Between TAC and KAC for years. The data that the main parts of the communities had no interaction with each-other ${ }^{1}$.

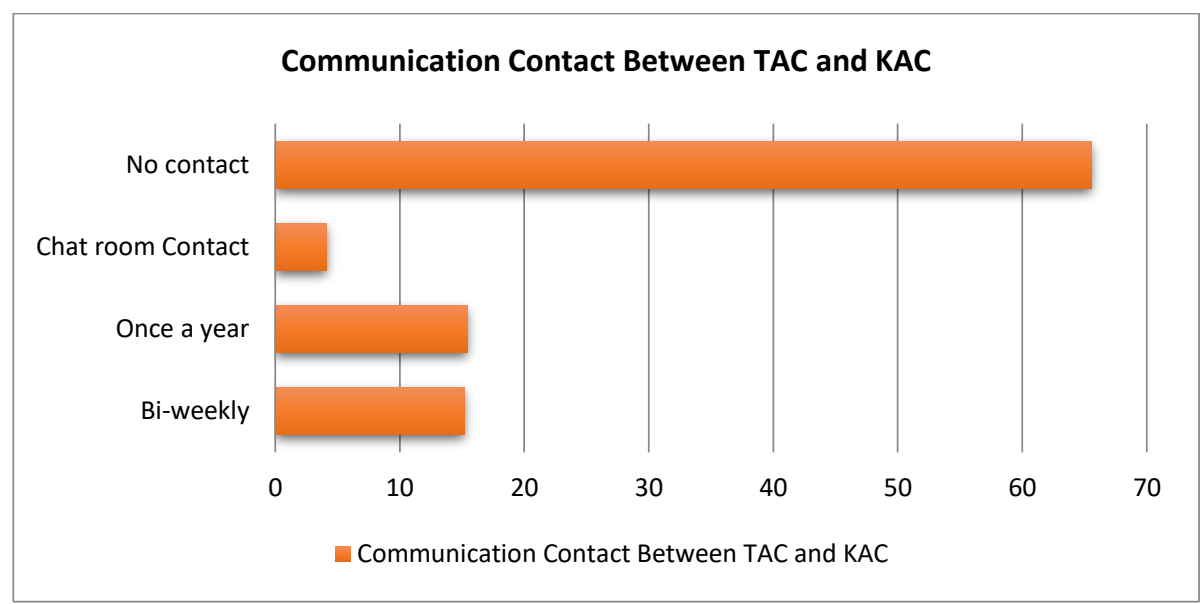

- $\quad$ Now the above situation change completely according to the data collected after the 1999, when the reports for communication from the statistical ${ }^{2}$ sources come as such, $46 \%$ of the statistics show that they had gotten in touch thru the chat rooms (mostly yahoo and AOL), $23 \%$ of the TAC had gotten in touch thru main contact, while $6 \%$ of the data claim that there was direct contact between family members, whom have left Kosovo due to the crises. Only $25 \%$ of the TAC and KAC were with no communication as stated by the data. By this data we can deduce that the main point contact was made thru social media, in its primary forms for sure, but still from social media.

\section{Communication between TAC and KAC during 1999-2000}

- Communication between TAC and KAC during 1999-2000

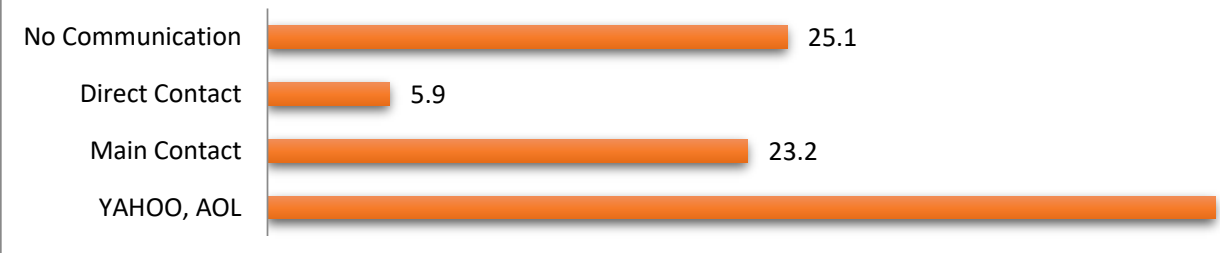

45.8

- $\quad$ Another interesting data that the statistics show is the way the communities impacted each other thru the humanitarian aid. The way the information was flowing shows how much impact different communities in the net brought people together. This is faced if we check the way the donations requests were answered from the TAC. $55 \%$ of the donations have been made thru direct instructions from the chat rooms and communities, followed by the $23 \%$ being made thru official channels, and $8 \%$ being made thru direct contact of the donator ( they send financial aid to a family member), while $14 \%$ has been made thru international media call.

\footnotetext{
${ }^{1}$ www.turkstat.gov.tr/

2 Anechiarico, F., \& Jocob, J. (1994). Vision of corruption control and the evolution of American public administration. Public Administration Review, 54(5), 463-473.
} 


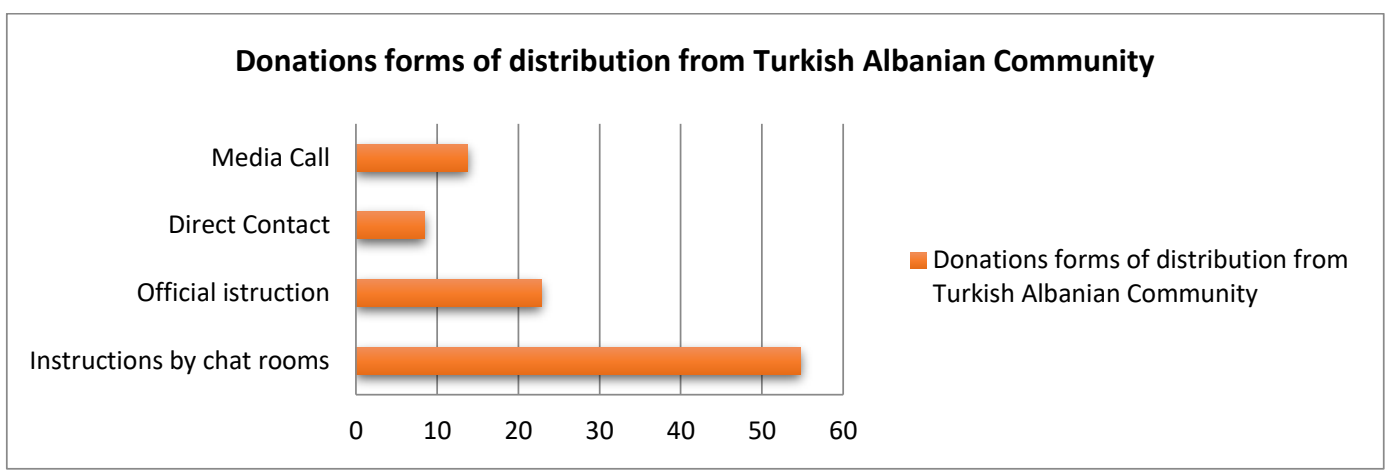

- $\quad$ The Next part of the data shows how did the communication ways stayed open after the 2000 , between the two communities: $73 \%$ of the contact between the TAC and the KAC is being kept by social media (different forms are shown, mostly email), $1 \%$ is traveling almost weekly, $2 \%$ of them communicate thru phone or other ways, and $24 \%$ of them shows that they have contact once a year. It is right to assume that mostly the social media is used since it is cheaper, and mostly is being used for keeping in touch for business matters between merchants, established or new enterprises.

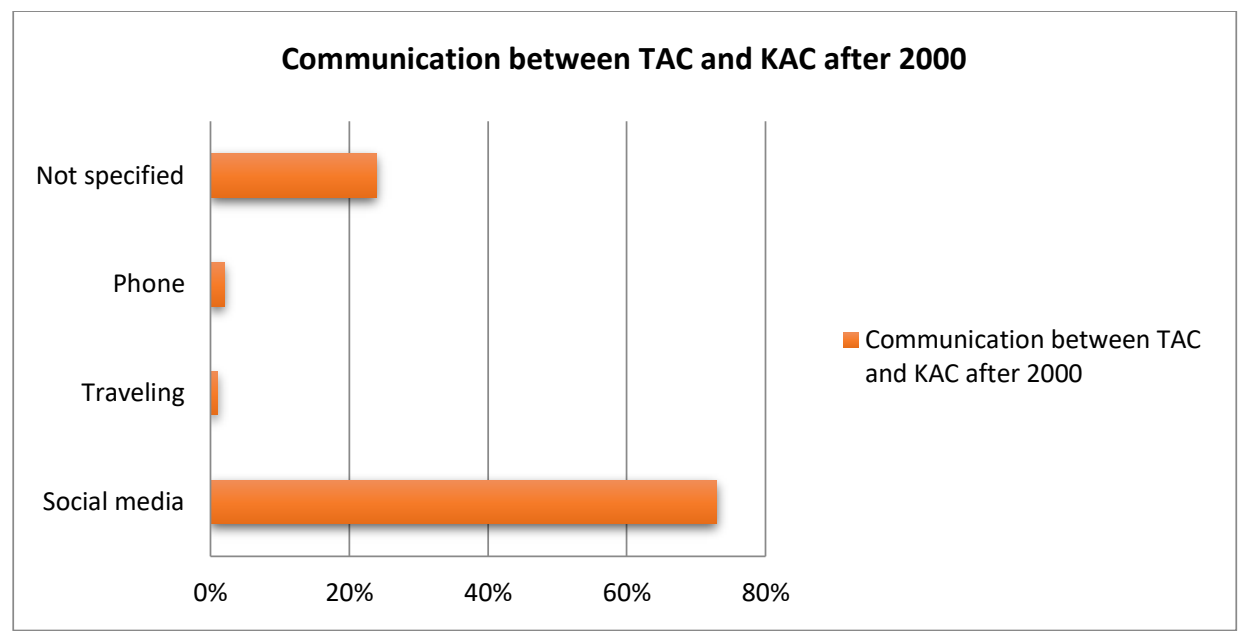

- $\quad$ To back up the above data below is a graph of the information taken from the Institutes of statistics of Kosovo and, the institute of Media and the Gallup institution in highlighting the data how the the investment of Turkey in Kosovo has been proceeding since 1900 to 2012. The actual number of turkish investment in ${ }^{1}$ Kosovo for 2012 is $61 \%$ of the foreign investment market, in 2002 there were an investment from ${ }^{2}$ Turkish companies up to $28 \%$, while in 1990 the number of investments from Turkey in Kosovo was $11 \%$ and the number of investments in 1900 from Turkey in Kosovo is $0 \%$. This show that the established comunication roads during

\footnotetext{
1 data.worldbank.org

2 Bertot, J. C. (2009). Public access technologies in public libraries: Impacts and implications. Information Technology \& Libraries, 28(2), 84-95.
} 
the road thru the social media, it went by and got stronger, bringing a new aspect in the equation, that of providing help for the future.

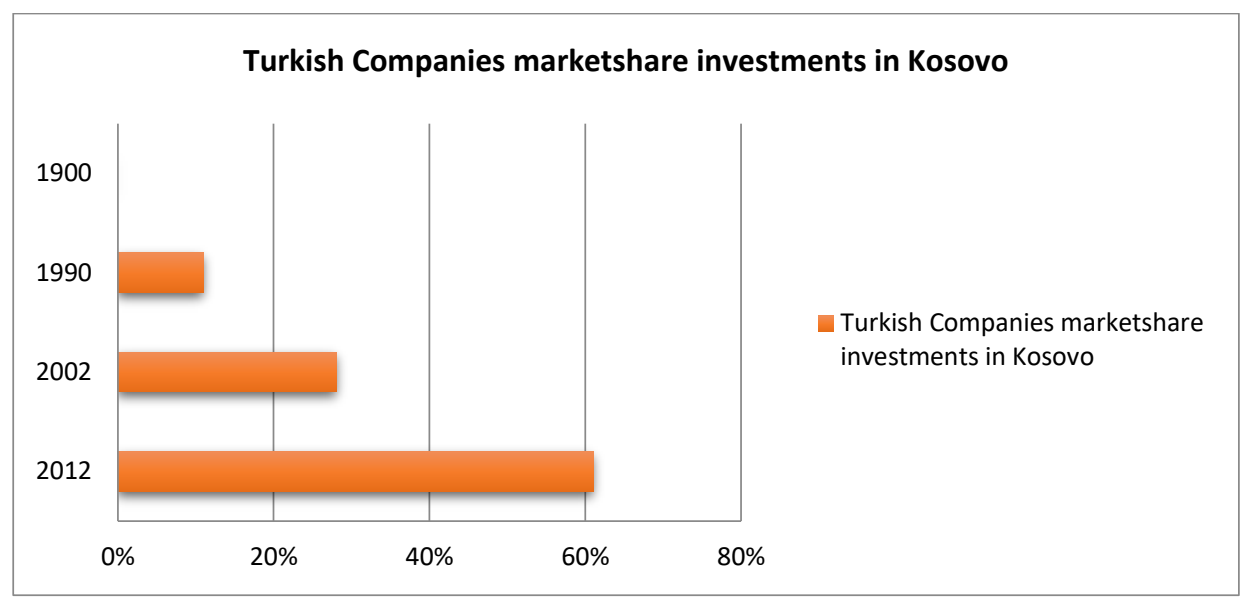

6.

\section{Conclusions}

As already demonstrated the main sources of information at the time to the crises the Kosovo was going thru were the chat rooms and the communities. Actually there were around 17 thousand chat rooms and communities at the time mainly ad operated by Albanians which were serving as a different source of information regarding the crises ${ }^{1}$ and possible ways to help the refugees, and more than half of them were kept in both Albanian and Turkish language. It provided a much more extended network then the actual media coverage, and it was so much more important because people were sharing ideas and information and were trying to come to the aid of those that were in the middle of a conflict.

The whole picture provided below point to the main potential of the social media which is the interconnecting of separated communities. The fastest way to come in contact is thru social media, and it is also a good elective, because it cannot become bothersome (you can log out if you are disturbed, or just block the person). Also it is a fast way to reenact lost connections which in the wholeness of them can make impact in the general picture.

The social media impacted in bringing together the two separated Albanian communities during the
a.)
It provided information and made contact between lost families
b.)
It provided help in a stressful and unmanageable situation
c.)
It opened new avenues for business enterprises.

\section{Bibliography}

[1] Anderson, T. B. (2009). E-government as an anti-corruption strategy. Information Economics and Policy, 21, 201-210.

[2] Anechiarico, F., \& Jocob, J. (1994). Vision of corruption control and the evolution of American public administration. Public Administration Review, 54(5), 463-473.

\footnotetext{
${ }^{1}$ Bernhard, N. E. (1993). Ready, willing, able: Network television news and the federal government, 1948-1953. In W. S. Solomon \& R. W. McChesney (Eds.), Ruthlesscriticism: Newperspectives in U. S. communication history (pp. 291-312). Minneapolis: University of Minnesota Press.
} 
[3] Axford, B., \& Huggins, R. (2003). Towards a political sociology of the Internet and local governance. Telematics and Informatics, 20, 185-192.

[4] Barzilai-Nahon, K. (2006). Gaps and bits: Conceptualizing measurements for digital divide/s. The Information Society, 22(5), 269-278.

[5] Bernhard, N. E. (1993). Ready, willing, able: Network television news and the federal government, 1948-1953. In W. $\mathrm{S}$. Solomon \& R. W. McChesney (Eds.), Ruthlesscriticism: Newperspectives in U. S. communication history (pp. 291-312). Minneapolis: University of Minnesota Press.

[6] Berra, M. (2003). Information communications technology and local development.Telematics and Informatics, 20, 215-234.

[7] Bertot, J. C. (2003). The multiple dimensions of the digital divide: More than the technology 'haves' and 'have nots'. Government Information Quarterly, 20(2), 185-191.

[8] Bertot, J. C. (2009). Public access technologies in public libraries: Impacts and implications. Information Technology \& Libraries, 28(2), 84-95.

[9] Bertot, J. C., \& Jaeger, P. T. (2008). The e-government paradox: Better customer service doesn't necessarily cost less. Government Information Quarterly, 25, 149-154.

[10] Bhatnagar, S. (2003). E-government and access to information. Global Corruption Report 2003. Washington DC: Transparency International.

[11] Braman, S. (2006). Change of state: Information, policy, and power. Cambridge, MA: Massachusetts Institute of Technology Press.

[12] Brautigam, D. (1992). Governance, economy, and foreign aid. Studies in Comparative International Development, $27(3), 3-23$.

[13] Brito, J. (2008). Hack, mash, \& peer: Crowdsourcing government transparency. Columbia Science and Technology Law Review, 9, 119-157.

[14] Brown, E., \& Cloke, J. (2004). Neoliberal reform, governance, and corruption in the South: Assessing the international anti-corruption crusade. Antipode, 36(2), 272-294.

[15] www.turkstat.gov.tr/

[16] data.worldbank.org

[17] www.allaboutturkey.com

[18] https://data.oecd.org/turkey.htm 